The Journal of the

World Universities Forum

Changes in Teacher Self-efficacy in the First Year of Primary School Teacher Education Study

SUSANNE GARVIS, DONNA PENDERGAST AND JAYNE KEOGH 


\section{JOURNAL OF THE WORLD UNIVERSITIES FORUM}

http://ontheuniversity.com/

First published in 2012 in Champaign, Illinois, USA

by Common Ground Publishing

University of Illinois Research Park

2001 South First St, Suite 202

Champaign, IL 61820 USA

www.CommonGroundPublishing.com

ISSN: $1835-2030$

(C) 2012 (individual papers), the author(s)

(C) 2012 (selection and editorial matter) Common Ground

All rights reserved. Apart from fair dealing for the purposes of study, research, criticism or review as permitted under the applicable copyright legislation, no part of this work may be reproduced by any process without written permission from the publisher. For permissions and other inquiries, please contact <cg-support@commongroundpublishing.com>.

Journal of the World Universities Forum is a peer-reviewed scholarly journal.

Typeset in CGScholar.

http://www.commongroundpublishing.com/software/ 


\title{
Changes in Teacher Self-efficacy in the First Year of Primary School Teacher Education Study
}

\author{
Susanne Garvis, Griffith University, Queensland, Australia \\ Donna Pendergast, Griffith University, Queensland, Australia \\ Jayne Keogh, Griffith Univerrsity, Queensland, Australia
}

\begin{abstract}
The beginning phase of teaching is a time of flux in the self-efficacy beliefs beld by teachers. Little is known, however, about the exact peaks and troughs that beginning teachers experience. While it is theorized that teacher self-efficacy increases during teacher education and declines during the beginning months of teaching (Tschannen-Moran and Woolfolk Hoy, 2007), little is known specifically about the changes during the period of engagement in teacher education programs. This paper reports on the first stages of a longitudinal study that sets out to explore pre-service teacher self-efficacy as students journey through their four-year program of study. It reports on initial levels of self-efficacy in the first week of entering a teacher education program and the changes after completion of one year of the degree. Findings are important as they provide insights for teacher educators and institutions to support the development of positive teacher self-efficacy beliefs.
\end{abstract}

Keywords: Teacher Self-efficacy, Beginning Teacher, Teacher Education

\section{INTRODUCTION}

$\mathrm{S}$

elf-efficacy is defined as "beliefs in one's capabilities to organize and execute the courses of action required to produce given attainments" (Bandura, 1997, p. 3). For pre-service teachers, this relates to the students' beliefs about their perceived capability to complete future teaching tasks. This includes their perceived ability to engage students in learning, provide instructional strategies in the classroom and promote classroom management strategies. The beliefs that pre-service teachers hold influence their effectiveness in the classroom (Bandura, 1997), making this an important area of research as teacher effectiveness is closely aligned to improved student learning outcomes (Hattie \& Timperley, 2007).

Research reveals that the beginning phase of teaching is a time of flux for teacher self-efficacy beliefs. However, little is known about the journey of pre-service teachers and the predicted peaks and troughs they experience along the way. While it is theorized that teacher self-efficacy increases during teacher education and declines during the beginning months of teaching (Tschannen-Moran \& Woolfolk Hoy, 2007) little is known about the changes within teacher education programs, and if there is a predictable pattern along the way.

This paper reports on the first stages of a longitudinal study exploring pre-service teacher self-efficacy. It reports on levels of change in teacher self-efficacy during the first year pre-service students are enrolled in a four year Bachelor of Education (primary) degree.

Journal of the World Universities Forum

Volume 5, Issue 1, 2012, http://ontheuniversity.com/, ISSN 1835-2030

(c) Common Ground, Susanne Garvis, Donna Pendergast, Jayne Keogh, All Rights Reserved, Permissions: cg-support@commongroundpublishing.com 


\section{Teacher Self-efficacy}

Teacher self-efficacy is an important motivational construct for beginning teachers. Self-efficacy beliefs are capable of predicting the outcomes that people expect (Bandura, 1997) leading to the assumption that teachers' beliefs regarding their own teaching capabilities create powerful influences on their overall effectiveness with students.

Self-efficacy theory is one of only a few conceptualisations of human control that describe a distinction between competence and contingency, used as a future oriented judgment. People use efficacy beliefs to guide their lives by being self-organising, proactive, self-regulating and self-reflecting (Bandura, 2006). This means that people may regulate their own behaviour through motivation, thought processes, affective states and actions or changing environmental conditions based around their efficacy beliefs. Perceived self-efficacy provides guidelines for enabling people to exercise some influence over how they live their lives.

Effective functioning requires skills as well as the efficacy belief to use them well (Bandura, 1997). They affect performance both directly and by influencing intentions. Moreover, they are not considered a stable character trait of an individual, but rather an active and learned system of beliefs in context (Bandura, 1997). Self-efficacy beliefs influence thought patterns and emotions that enable actions in which people can pursue goals, rebound from setbacks and exercise some control over events that affect their lives (Bandura, 1986, 1993, 1996, 1997). From this perspective, self-efficacy operates as a key aspect in a generative system of human competence.

People with higher self-efficacy will set higher goals and commit to them. Once an action has been taken highly self-efficacious people invest more effort and persist longer than those with low self-efficacy. High self-efficacy also allows individuals to select challenging settings, explore their environment and create new environments if needed. Alternatively, weak efficacy beliefs are easily negated by disconfirming experiences that may cause anxiety, depression and helplessness within the specific context (Bandura, 1997).

Teacher self-efficacy is developed by four sources of efficacy: emotional arousal; mastery experience; vicarious experience; and, verbal persuasion. Emotional arousal concerns the emotional input that is associated with completing the task. For instance, affective states caused by emotional arousal may create negative beliefs for beginning teachers (Bandura, 2006). For example, an individual with previous personal failure may create high emotional arousal, leading to fear provoking thoughts that far exceed what would actually occur if the individual attempted the feared task (Tosun, 2000). High emotional arousal may also be created by observing failure in a similar situation, or from negative verbal persuasion.

Mastery experience is the most powerful source of self-efficacy and develops from the belief of completing a task successfully. As teachers develop mastery experiences, they will rely on these heavily as memories and interpretations of similar past teaching experiences (TschannenMoran, Woolfolk Hoy \& Hoy, 1998). Mastery innovations have included forms of self-reflection (Henson, 2001; Moss, 1997; Shachar \& Schumuelevitz, 1997), that facilitate the use of selfregulatory processes in interpreting enactive mastery experiences, enhancing self-efficacy (Schunk \& Zimmerman, 1997).

Verbal persuasion is the influence of other verbal feedback on the task. Tschannen-Moran and Woolfolk Hoy (2007) found that support of colleagues and the community made significant contributions to explaining variances in beginning teachers self-efficacy beliefs. No impact was found on beginning teacher self-efficacy from the support of administrators. Tschannen-Moran and Woolfolk Hoy (2007, p. 954) explain this as "because of the dearth of meaningful feedback from administrators in traditional supervisory practice, it is not surprising that teachers do not look to school leaders as significant sources to inform their self-efficacy judgments".

Finally, vicarious experience is the influence of modeling on teacher self-efficacy. Vicarious experience is effective when the observer of the modeled activities believes they are capable of 
completing the same task successfully. Vicarious experiences may be of particular importance when limited prior experiences exist on which to base efficacy beliefs (Bandura, 1997). Modes of vicarious experiences include modeling, performance similarity, attribute similarity, model competence, coping versus mastery modeling and multiplicity and diversity of modeling. The individual learns through observation (Bandura, 1986) and as such, modeling is effective for pre-service teaching as it has the ability to inflate levels of efficacy during the 'apprenticeship of observation' (Lortie, 1975). In particular, cognitive modeling has been found to be more effective in developing positive self-efficacy in pre-service teachers than direct instruction (Gorrell \& Capron, 1990). For example, a person may rehearse and model the situation in their mind first.

As yet, limited studies in Australia have explored the peaks and troughs associated with the development of teacher self-efficacy during teacher education. The studies referred to in this review are contextualized in North America and Europe. Hence, there is a paucity of knowledge regarding the sources of efficacy that directly influence teacher self-efficacy as pre-service teachers complete their teacher education in Australia. This study, as part of a larger longitudinal study, will make a contribution towards addressing this deficit.

\section{Focus of Study}

The longitudinal study from which this paper draws a subset of data tracks the self-efficacy of pre-service student teachers as they journey through a four-year Bachelor of Education (Primary) degree. This paper reports on the initial change over the first year of the 4 year program by comparing self-efficacy beliefs at the point of entry with the same measure at the commencement of the second year of study.

\section{Method}

In 2010, 205 Bachelor of Education (Primary) pre-service teachers were invited to participate in the Longitudinal Self-efficacy Pre-service Teacher Education Research Project to be conducted during their program of study. A total of 156 respondents were recruited through the completion of the instrument and consent form, representing a $76 \%$ response rate. Respondents were advised that, upon return of the questionnaire all information would immediately be de-identified. During the first week of the second year of study, the pre-service teachers were asked to complete the survey for the second time. Seventy-one respondents completed the survey out of a total of 162 present at the time of administration of the survey, representing a $42 \%$ response rate.

The Teachers' Sense of Efficacy Scale was used to measure perceived teacher self-efficacy levels (Tschannen-Moran and Woolfolk Hoy, 2001). This measure consists of 24 items, assessed along a 9-point continuum with anchors at 1-Nothing, 3-Very Little, 5-Some Influence, 7-Quite A Bit, and 9-A Great Deal. The instructions direct the teacher to, "Please respond to each of the questions by considering the combination of your current ability, resources, and opportunity to do each of the following in your present position (Tschannen Moran and Woolfolk Hoy, 2007, p. 948).

All data was screened for completeness and accuracy before input into the software program SPSS16. Each questionnaire item was analysed, before cross comparative analysis was conducted. Factor analysis was conducted to verify the multifaceted structure of efficacy beliefs (Bandura, 1997), helping to verify the homogeneity of the items (Bandura, 2006). The Teachers' Sense of Efficacy Scale (Tschannen-Moran and Woolfolk Hoy, 2001) has consistently produced high rating for reliability. Cronbach's alpha have been reported as 0.94 (Tschannen-Moran and Woolfolk Hoy, 2001), 0.95 (Tschannen Moran and Woolfolk Hoy, 2007) and 0.96 (Garvis, 2009). 
The Teachers' Sense of Efficacy Scale consists of three subscales: instructional strategies; classroom management; and, student engagement. Sample items include:

Efficacy for Instructional Strategies

- To what extent can you provide an alternative explanation or example when students are confused?

- How well can you implement alternative teaching strategies in your classroom?

Efficacy for Classroom Management

- How much can you do to control disruptive behaviour in the classroom?

- How much can you do to calm a student who is disruptive or noisy?

Efficacy for Student Engagement

- How much can you do to motivate students who show low interest in schoolwork?

- How much can you do to get students to believe they can do well in school work?

The scale was administered to the pre-service teacher cohort as part of a longitudinal study to measure the peaks and trough in their developing teacher self-efficacy.

\section{Participants}

The participants were pre-service teachers currently studying a teacher education course at Griffith University Gold Coast campus. During the administration of the first survey, all students were in the first week of the first semester of their program. Students were yet to experience any university content or classroom professional experience. While the questionnaire was distributed to all students, they were not compelled to complete them, so it may have been only been committed or engaged students who returned the usable questionnaire.

When the survey was again administered in the second year of study, students had experienced one week of observation in a school during their final weeks in year one. Students had also completed eight subjects in educational studies ranging from sociology, information and technology, early years education, music education and literacy education.

For the respondents in the first survey, $73 \%$ were female and $27 \%$ were male. They ranged from 17 years of age to 58 years of age, with $68 \%$ of the sample aged 21 years and under. In the second survey, $78 \%$ were female and $22 \%$ were male. Respondents were aged from 18 to 59 years, with $56 \%$ aged under 21 years of age.

\section{Findings}

Findings reveal that overall teacher self-efficacy decreased between the first and the second year of study (decline from mean of 7.55 to 7.31 ) with all three of the subscales-student engagement, instructional strategies and classroom management-declining over this period (refer to table 1).

Table 1: Means for the $1^{\text {st }}$ and $2^{\text {nd }}$ Survey for Total Scale (all 24 Questions) and the Three Subscales (with SD)

\begin{tabular}{|l|c|c|}
\hline Subscale & $\begin{array}{c}\text { Survey 1 Mean (SD) } \\
\mathbf{N = 1 5 6}\end{array}$ & $\begin{array}{c}\text { Survey 2 Mean (SD) } \\
\mathbf{N = 7 1}\end{array}$ \\
\hline OSTES & $7.55(0.68)$ & $7.31(0.81)$ \\
\hline Efficacy in student engagement & $7.57(0.75)$ & $7.35(0.86)$ \\
\hline Efficacy in instructional strategies & $7.46(0.78)$ & $7.26(0.89)$ \\
\hline Efficacy in classroom management & $7.62(0.77)$ & $7.31(0.89)$ \\
\hline
\end{tabular}


The alpha reliabilities for the $1^{\text {st }}$ and $2^{\text {nd }}$ survey are represented below in table 2 . Previous studies suggest alpha reliabilities of between 0.92 to 0.96 for the full scale (Garvis \& Pendergast, 2010; Tschannen-Moran \& Woolfolk Hoy, 2007) and 0.86 to 0.90 for the subscales (TschannenMoran \& Woolfolk Hoy, 2007).

Table 2: Alpha Reliability for the $1^{\text {st }}$ and $2^{\text {nd }}$ Survey for Total (all 24 Questions) and the Three Subscales

\begin{tabular}{|l|c|c|}
\hline Subscale & Survey 1 Alpha & Survey 2 Alpha \\
\hline OSTES & 0.92 & 0.95 \\
\hline Efficacy in student engagement & 0.78 & 0.86 \\
\hline Efficacy in instructional strategies & 0.87 & 0.89 \\
\hline Efficacy in classroom management & 0.84 & 0.86 \\
\hline
\end{tabular}

Correlational analysis for age was conducted to determine a possible relationship. Findings in graph 1 and table 3 suggest little to no relationship between age of respondent and their OSTES score. Older beginning teachers do not have higher self-efficacy than younger beginning teachers.

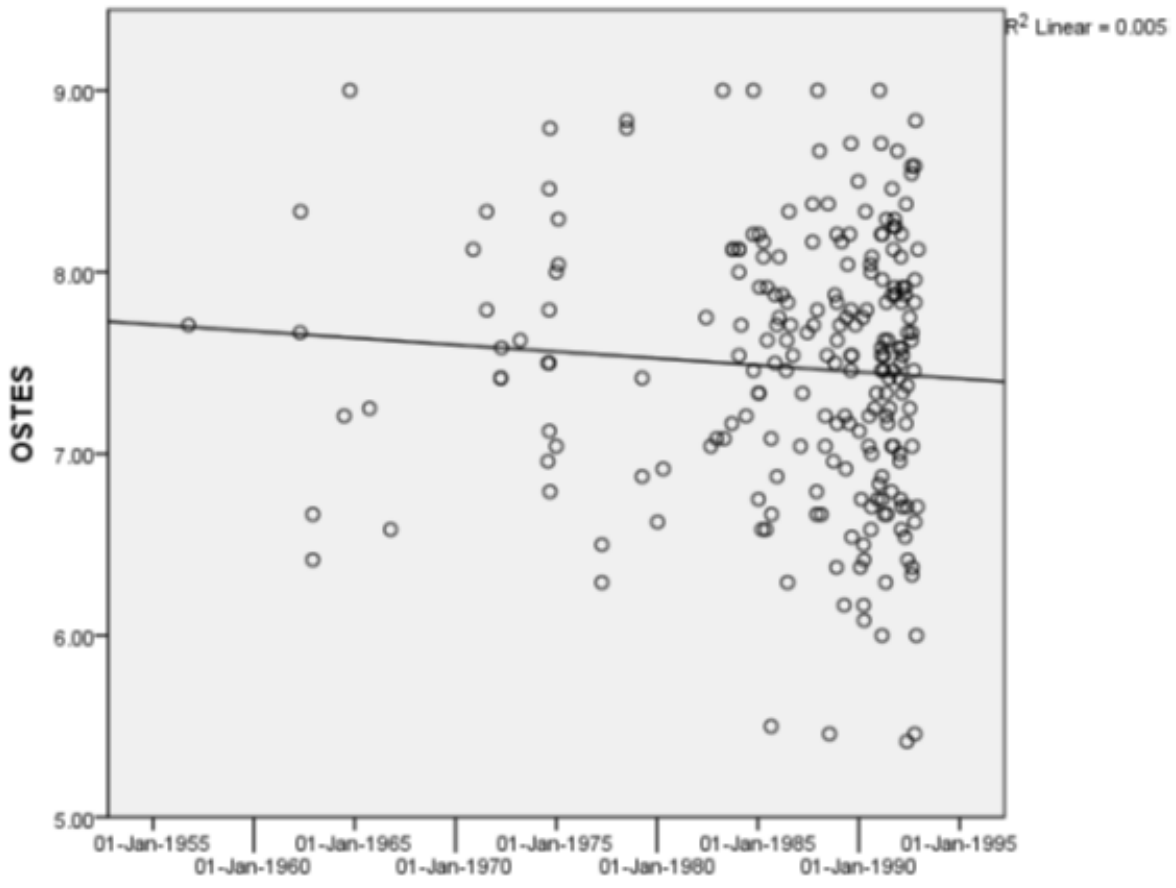

Birthdate

Graph 1: Co-relational Analysis for Age and Gender 
Table 3: Correlations between Birth Date (as a Proxy for Age) and OSTES Subscale Scores

\begin{tabular}{|l|c|c|}
\hline Subscale & Survey 1 Pearson & Survey 2 Pearson \\
\hline OSTES & -0.140 & 0.029 \\
\hline Efficacy in student engagement & -0.070 & 0.014 \\
\hline Efficacy in instructional strategies & -0.124 & 0.072 \\
\hline Efficacy in classroom management & $-0.176^{*}$ & -.006 \\
\hline * significant at 0.05 level.
\end{tabular}

Correlational analysis was also conducted for each of the subscales. There was a statistically significant relationship between age and self-efficacy in classroom management in the first survey. This difference was not repeated when the data was collected in the second year of study.

A correlational analysis was also conducted to determine if gender was a contributor to teacher self-efficacy. Findings reveal there was a statistically significant correlation between gender and self-efficacy beliefs in classroom management in the first data set. However, this finding was not repeated in the second data set.

\section{Discussion and Implications}

This research contributes to building a better understanding of the development of self-efficacy during the pre-service education phase of the journey to become a teacher. In this dataset taken from a 4 year longitudinal study of Bachelor of Education (Primary) students, pre-service teacher self-efficacy decreased for all three subscales of self-efficacy, viz: instructional strategies; classroom management; and, student engagement, in the time between commencing the program and the second year of study. This means the students had greater self belief at the commencement of their program of study, compared to their beliefs after twelve months of study. In this time, students were engaged in just one week of practical experience (mastery experience), with other general education courses providing vicarious experience and verbal persuasion. In workshops and tutorials students were shown models of teaching tasks and there was a commencement of the scaffolding of developing a repertoire of teaching skills. The intention of the general education programs was to build understanding about teaching and learning and also discipline specific knowledge.

One possible explanation for this decline may be due to an inflation in self-efficacy at the time of entering the teacher education course. For students entering the program, their level of self-efficacy belief was, at that time, largely informed by vicarious experiences (modeling) of the teachers they had experienced during their own schooling. Yet, to enter a classroom for professional experience, the pre-service teachers initially believed they were highly capable to carry out the actions of a teacher. One year on, with greater insight into the role of the teacher and being able to reflect on their own level of perceived capability of teaching, pre-service teachers rated their self-efficacy lower on all three scales of measures.

The small significance in the correlations with gender and age disappeared in the second survey. As such, gender and age does not appear to contribute to teacher self-efficacy. It appears that the main influence to teacher self-efficacy are the sources of efficacy that are experienced in the teacher education course.

It will be interesting to note what will happen to the level of teacher self-efficacy for these pre-service teachers over the next two years of their teacher education program and their commencement into beginning to teach. The longitudinal study is intended to document the peaks and troughs of teacher self-efficacy in teacher education. It is hoped that teacher self-ef- 
ficacy does not continue to fall throughout the beginning phase of teaching but becomes stable before teachers enter the profession. Research suggests that teacher self-efficacy declines during the beginning months of starting to teach in a classroom and will become stable as the teacher grows in mastery experience.

This study, like all self-efficacy studies, is limited by the participants' perceptions of their efficacy being self-reported. Participants with higher levels of self-efficacy may have completed the survey. Since the data was also self-reported, no verification of actual level of teacher selfefficacy could be made by observation of the pre-service teacher in a classroom context.

\section{Conclusion}

This study has shown a decline of reported self-efficacy by pre-service teachers over the first year of their study in a four year teacher education program. The study moves towards helping to fill the void of understanding the sources that help support and develop teacher self-efficacy. As more data is collected in this longitudinal study, teacher self-efficacy will be able to be mapped across the teacher education program. The study will also be able to determine sources of efficacy that contribute to supporting and developing the teacher self-efficacy of the future teachers. 


\section{REFERENCES}

Bandura, A. (1993). Perceived self-efficacy in cognitive development and functioning. Educational Psychologist, 28(2), 117-148.

Bandura, A. (1995). Manual for the construction of self efficacy scales. Stanford University, Stanford, CA. Published in F. Pajares \& T. Urdan (Eds.). Self-efficacy beliefs of adolescents, (Vol. 5., pp. 307-337). Greenwich, CT: Information Age Publishing.

Bandura, A. (1996). Ontological and epistemological terrains revisited. Journal of Behavior Therapy and Experimental Psychiatry, 27, 323-345.

Bandura, A. (1997). Self-efficacy: The exercise of control. New York: W.H. Freeman.

Bandura, A. (2006). Adolescent Development from an Agentic Perspective. In F. Pajares \& T. Urdan (Eds.), Self-efficacy beliefs of Adolescents (pp. 1-44). Connecticut: Information Age Publishing.

Garvis, S. (2009). Improving the teaching of the arts: Pre-service teacher self-efficacy towards arts education. Us-China Education, Review, 6(12), 23-28.

Garvis, S., \& Pendergast, D. (2010). Supporting novice teachers of the arts. International Journal of Education and the Arts, 11(8). Retrieved 11 February 2011 from http://www.ijea.org/v11n8

Gorrell J., \& Capron E. (1991) Cognitive modeling and self-efficacy: effects on preservice teachers' learning of teaching strategies. Journal of Teacher Education, 41(4), 15-22.

Hattie, J., \& Timperley, H. (2007). The power of feedback. Review of Educational Research, $77(1), 81-112$.

Henson, R.K. (2001). The effects of participation in teacher research on teacher efficacy. Teaching and Teacher Education, 17, 493-508.

Lortie, D.C. (1975). Schoolteacher: A sociological study. Chicago: University of Chicago Press.

Moss, C. M. (1997). Systematic self-reflection: Professional development for the reflective practitioner. Paper presented at the annual meeting of the American Educational Research Association, Chicago, IL.

Schunk, D. H. \& Zimmerman, B. J. (1997). Social origins of self-regulatory competence. Educational Psychologist, 32(4), 195-208.

Shachar, H. \& Shumuelevitz, H. (1997). Implementing cooperative learning, Teacher collaboration and teachers' sense of efficacy in heterogeneous high schools. Contemporary Educational Psychology, 22, 53-72.

Tosun, T. (2000). The beliefs of pre-service elementary teachers toward science and science teaching. School Science and Mathematics, 100, 374-379.

Tschannen-Moran, M., Woolfolk Hoy, A., \& Hoy, W.K. (1998). Teacher efficacy: its meaning and measure. Review of Educational Research, 68, 202-248.

Tschannen-Moran, M., \& Woolfolk Hoy, A.W. (2001). Teacher efficacy: Capturing an elusive construct. Teaching and Teacher Education, 17(7), 783-805.

Tschannen-Moran, M., \& Woolfolk Hoy, A. (2007). The differential antecedents of self-efficacy beliefs of novice and experienced teachers. Teaching and Teacher Education, 23, 944-956. 


\section{ABOUT THE AUTHORS}

Dr. Susanne Garvis: The main focus of Susanne Garvis's work at the University of Queensland has been on the professional development of pre-service teachers. Susanne's research and teaching interests include teacher education and arts education, with a particular interest in music. Susanne is currently undertaking a $\mathrm{PhD}$ study into the development of beginning teacher self-efficacy beliefs in arts and music education.

Prof. Donna Pendergast: Associate Professor Donna Pendergast has conducted a number of national research projects of significance, including "Beyond the Middle", which investigated literacy and numeracy in middle schooling; and "Lifelong Learning and Middle Schooling". She has completed an evaluation of the Education Queensland Virtual Schooling Service and is often employed as a consultant to review school reform initiatives. Donna has several books published of relevance to contemporary teacher work, including Teaching the Middle Years; The Millennial Adolescent; and Groovy Chicks and Blokey Blokes. Donna is highly sought after as a speaker on the topic of the MilGen and teaching, and has completed several intergenerational studies in content areas.

Dr. Jayne Keogh: Jayne Keogh is a Lecturer in Education with expertise in diversity and the middle years of schooling. She is a qualitative researcher with a particular interest in the experiences of beginning teachers and pedegogic practice. 

The Journal of the World Universities Forum seeks to explore the meaning and purpose of the academy in a time of striking social transformation. The journal brings together university administrators, teachers and researchers to discuss the prospects of the academy and to exemplify or imagine ways in which the university can take a leading and constructive role in the transformations of our times.

Today, universities face significant challenges to their traditional position in society. Contemporary knowledge systems are becoming more distributed and learning ubiquitous. Where does this leave the university-as a historically specialized and privileged place for certain kinds of knowledge and learning, as an institutionally bounded space? What do these changes mean for the mission and structures of the renewed university? What are emerging as principal areas of the academic interest? These are some of the key questions addressed by the journal.

The Journal of the World Universities Forum is a peerreviewed scholarly journal.

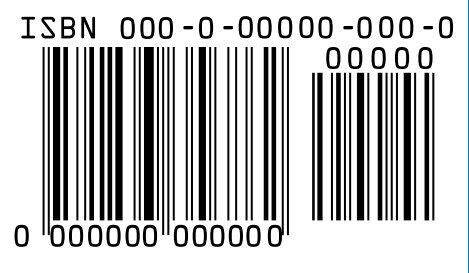

